University of Nebraska - Lincoln

DigitalCommons@University of Nebraska - Lincoln

\title{
Public Engagement for Informing Science and Technology Policy: What Do We Know, What Do We Need to Know, and How Will We Get There?
}

Lisa M. Pytlik Zillig

University of Nebraska, Ipytlikz@nebraska.edu

Alan Tomkins

University of Nebraska, atomkins@nebraska.edu

Follow this and additional works at: https://digitalcommons.unl.edu/publicpolicytomkins

Part of the Public Policy Commons

Pytlik Zillig, Lisa M. and Tomkins, Alan, "Public Engagement for Informing Science and Technology Policy: What Do We Know, What Do We Need to Know, and How Will We Get There?" (2011). Alan Tomkins Publications. 18.

https://digitalcommons.unl.edu/publicpolicytomkins/18

This Article is brought to you for free and open access by the Public Policy Center, University of Nebraska at DigitalCommons@University of Nebraska - Lincoln. It has been accepted for inclusion in Alan Tomkins Publications by an authorized administrator of DigitalCommons@University of Nebraska - Lincoln. 
Published in Review of Policy Research 28:2 (March 2011), pp. 197-217; doi: 10.1111/j.15411338.2011.00489.x Copyright (C) 2011 by The Policy Studies Organization; published by Wiley-Blackwell. Used by permission. The definitive version is available at http:/ / www3.interscience.wiley.com

We acknowledge the invaluable contributions of our colleagues at the Public Policy Center, Tarik AbdelMonem, Joseph Hamm, Mitchel Herian, Jamie Marincic, Sarah Michaels, and Mario Scalora, as well as Peter Muhlberger from Texas Tech University, related to issues of public engagement, and to Yuris Dzenis, Susan Poser, and Joseph Turner for their contributions to issues related to nanotechnology.

Portions of this work were presented as "Public Engagement for Informing Science and Technology Policy: What Do We Know, and What Do We Need to Know?" at Policy Studies Organization's Dupont Summit, "The New Administration's Challenges on Science \& Technology: Staying the Course in Times of Crisis," Washington, DC (December 2009).

\title{
Public Engagement for Informing Science and Technology Policy: What Do We Know, What Do We Need to Know, and How Will We Get There?
}

\author{
Lisa M. PytlikZillig and Alan J. Tomkins \\ Public Policy Center, University of Nebraska
}

\begin{abstract}
This article examines social science relevant to public engagements and identifies the challenges to the goal of meaningful public input into science and technology policy. Specifically, when considering "which forms, features, and conditions of public engagement are optimal for what purposes, and why?" we find social science has not clarified matters. We offer a model to guide systematic research that defines and empirically connects variations in features and types of public engagement activities to specifically defined variations in effective processes and outcomes. The specification of models, as we have done, will guide policy makers, practitioners, and the public in determining what kinds of engagement techniques are optimal for what kinds of purposes. Our model is presented to start conversations and inspire research that in the future should help to ensure meaningful public participation that meets the promise of contributing thoughtful societal values and perspectives into governmental policies impacting science and technology research.
\end{abstract}

Keywords: public engagement, science and technology policy

Public engagement is a valuable means to provide societal perspectives concerning the policy, legal, ethical, and other impacts of scientific and technological research. Input from the public has been provided via such methods as surveys, legislative hearings, public meetings, and notice and comment opportunities. In recent decades, more interactive public engagements, involving residents, scientists, and policy makers, have been convened to help shape science and technology policy. These approaches, including citizen juries, consensus conferences, and citizen deliberations (see generally, Delli Carpini, Cook, \& Jacobs, 2004), have been applauded for giving the public a more meaningful role in shaping science and technology policy while, at the same time, castigated for not really 
engaging the public (e.g., Fiorino, 1990; Lewenstein \& Brossard, 2006; Rowe \& Frewer, 2000, 2005). For example, it has been argued the engagements often do not take place early enough in the decision-making process, and the impacts of public inputs on policy outputs are unclear and uncertain (Wilsdon \& Willis, 2004).

To achieve the objective of meaningful and influential public input to the policy-making process related to science and technology, public engagements must be effective for that purpose. However, the public engagement social science literature has provided little systematic guidance for selecting which public engagement methods to use for which purposes. There are numerous public engagement methods available to use, and the costs associated with them vary considerably. Town hall meetings, for example, are quite inexpensive, but perhaps they are not as useful for helping inform policy. Most agree the public input obtained from town hall meetings across the United States on health-care reform in the summer of 2009 provided little policy-relevant information (Collins, 2009; Urbina, 2009; Urbina \& Seelye, 2009). On the other hand, there is no empirical evidence that a different kind of public input forum (see generally, Mitton, Smith, Peacock, Evoy, \& Abelson, 2009) would have provided a more nuanced sense of the public's policy (as opposed to political) preferences or that more useful policy information would have been adduced had more expensive and carefully planned public engagements been conducted (see, e.g., Littlejohns \& Rawlins, 2009).

Thus, in spite of the widespread perceived importance of public engagement in policy making, in general, and for science and technology policy in particular, there is a serious gap in scientific knowledge concerning which forms or features of public engagement, and conditions for such engagements, will result in effective engagements, that is, engagements that are meaningful to participants and produce information and insights useful both to scientists and policy makers. The field lacks theoretical models that will advance research and guide practitioners in their design of public engagement activities. Lack of such models and guidance has resulted in public engagements that sometimes have negative effects, resulting in outcomes such as group conflict, polarization, dissatisfaction among participants, or the failure to obtain public input that benefits policy (e.g., Delli Carpini et al., 2004; Sunstein, 2005).

We explore the possibilities of public engagements to inform science and innovation policy in the context of nanotechnology. We examine the social science literature relevant to nanotechnology public engagements in order to identify and assess the challenges that confront the goal of and meaningful public input. These challenges can be summarized as stemming from the lack of an answer to the question of which forms, features, and conditions of public engagement are optimal for what purposes, and why?

Although the focus of our article is on nanotechnology, the issues raised are applicable to not only science and technology issues but also to public engagement related to policy making in virtually any context. Further, although the majority of our focus in this article is on practices in the United States and Europe, public engagements concerning nanotechnology have been conducted, and continue to take place, across the globe (e.g., Australia: Cormick, 2009; Department of Innovation, Industry, Science and Research, Australian Government, 2010; Katz, Lovel, Mee, \& Solomon, 2005; Kyle \& Dodds, 2009; Solomon, Katz, Lovel, \& Mee, 2005; Brazil: Macnaghten \& Guivant, in press; India: The Energy and Resources Institute [TERI], 2009, 2010; South Africa: South African Agency for Science and 
Technology Advancement, 2010; Zimbabwe: Grimshaw, Stilgoe, \& Gudza, 2006). Indeed, since 2003, there have been more than 100 major engagement activities focused on nanotechnology across the globe (e.g., Center for Nanotechnology in Society, 2010; Department of Innovation, Industry, Science and Research, Australian Government, 2010; European Commission, 2009; see generally, Laffite \& Joly, 2008).

\section{Public Engagement and Nanotechnology}

Conceptually, the interest in the American public's input into science and technology policy is part of the greater issue of open and transparent government (e.g., Brief Amicus Curiae in Support of Respondents Sierra Club and Judicial Watch, Inc., 2004; Brito, 2008; Fenster, 2006; Fung, Goldman, McCoy, \& Wright, 2009; Holdren, 2010; Kundra \& Noveck, 2009; National Academy of Public Administration, 2009; Obama, 2009; Office of Science and Technology Policy, 2010) and the democratic ideal (Dahl, 1994; Delli Carpini et al., 2004; Fishkin, 1991; Meadowcroft, 2004; Pateman, 1970; Verba \& Nie, 1972). The specific idea that the public should weigh in on science and technology is of fairly recent vintage: Its roots trace back to the ethical lapses of scientists that resulted in Congress mandating stricter oversight of the conduct of science via institutional review boards that included citizen representatives (e.g., National Commission for the Protection of Human Subjects of Biomedical and Behavioral Research, 1979; Petersen, 1984; Rothman, 1991; Weisstub, 1998). The explicit purpose of including citizen representatives was to ensure that public values were included in scientific considerations. Basing its approach on the significant scientific, political, and societal successes of the ethics, law, and social implications [Ethical, Legal and Social Implications (ELSI)] initiative of the transformative human genome project of the 1990s (ELSI Research Program, 2009, and links therein), Congress provided for an even greater role for the public in its 21st Century Nanotechnology Research and Development Act (2003) (Sargent, 2010). The Nanotechnology Act calls for public participation in strategic decision making related to nanotechnology development, specifically, "the convening of regular and ongoing public discussions, through mechanisms such as citizens' panels, consensus conferences, and educational events, as appropriate" (§ 2(b)(10)).

Congress' decision to mandate public input for science and technology purposes was unprecedented in U.S. history (see, e.g., Jasanoff, 2003). Public engagement, Congress indicated, promises the possibility of interconnections among science, technology, and society, allowing science and society to shape one another, and providing a critical element for understanding the ethical, legal, and other societal "impacts of new technologies on individuals and society" (Ethical, Legal, and Other Societal Issues, n.d.). It is "vital in the nanotechnology R\&D enterprise" (Societal Dimensions, n.d.) (see also Lewenstein, 2005; Roco, 2003).

The routine use of public engagement for general policy-making purposes, including but not limited to science and technology policy, has been commonplace in the United Kingdom since the Blair Administration (e.g., Better Regulation Executive, 2008; Council for Science and Technology, 2005; House of Lords, 2000). Public engagement also has been routinely utilized throughout the European Union (e.g., European Commission, 
2007a, 2007b, 2008; see generally European Commission, 2009; see also Hullmann, 2008; Involve, 2008; Kaufmann, Audétat, \& Joseph, 2009; Macnaghten, Kearnes, \& Wynne, 2005; Rogers-Hayden \& Pidgeon, 2006) to focus on issues related to nanotechnology policy. Since 2003, there have been approximately 100 major engagement activities focused on nanotechnology in the United States and elsewhere around the world (Laffite \& Joly, 2008; see generally, Center for Nanotechnology in Society, 2010; Department of Innovation, Industry, Science and Research, Australian Government, 2010; European Commission, 2009).

The engagements that have taken place have varied widely, covering the spectrum of public engagement opportunities and providing some useful initial informationboth concerning nanotechnology and concerning the types of information that might be gleaned from different methods. For example, in their study of nanotechnology focus group conversations in the UK, Kearnes and Wynne (2007) found that many participants had an ambivalent attitude toward technological advances in general and not surprisingly, toward nanotechnology as well. In the United States, Hamlett, Cobb, and Guston (2008) conducted a series of six nanotechnology consensus conferences that confirmed the public's lack of sophisticated knowledge and ongoing concerns concerning nanotechnology (see also, Macoubrie, 2005; Solomon et al., 2005). Opinion surveys, in contrast, have shown more positive attitudes, particularly in instances in which people have higher levels of knowledge concerning the issues (Cobb \& Macoubrie, 2004; Currall, King, Lane, Madera, \& Turner, 2006; Scheufele \& Lewenstein, 2005; Scheufele et al., 2007). Meanwhile, Pidgeon, Harthorn, Bryant, and Rogers-Hayden (2009) conducted four deliberative workshops, two in Santa Barbara and two in Cardiff and compared with survey methods, found more nuanced opinions concerning nanotechnology, including strong differences in public views concerning different nanotechnology applications (in health and energy domains) and subtle differences in United States versus British views. Finally, an experimental study by Kahan, Braman, Slovic, Gastil, and Cohen (2009) indicated risk versus benefit perceptions concerning nanotechnology vary depending on psychosocial variables such as cultural cognition and political characteristics.

In addition to the different findings associated with different participation methods, findings can differ within methods. To explain such differences, Rogers-Hayden and Pidgeon (2006), for example, suggested the contextual framing of participatory discussions may influence participants' ability to offer meaningful input (see also Kahan et al., 2009). They argued meaningful engagement of the public concerning nanotechnology entails moving beyond discussions focused on risk to broader, less tangible topics concerning values and governance. Engagement or deliberation process details may also influence perceptions concerning nanotechnologies. Hamlett and Cobb (2006) utilized small-scale discussions concerning nanotechnology based on the consensus conference model. Though they were specifically examining potential opinion polarization, they noted that discussion facilitation, composition of educational materials, interaction with experts, and the selection process of experts can impact quality of discussion and participants' opinions.

Taken together, the varied and often disparate findings within the public participation in nanotechnology literature suggest the vital importance of understanding which types or features of participation activities lead to what outcomes and why. Without such understanding, it is difficult to interpret the findings from any given engagement. For ex- 
ample, what should policy makers weigh more heavily: positive views concerning nanotechnology expressed in one engagement context or more cautious or negative views expressed in another? Although, as reviewed earlier, some preliminary associations between features and outputs have been noted, there is little theoretical guidance to explain contradictory results that have been obtained (e.g., Brossard \& Lewenstein, 2009; Cobb \& Macoubrie, 2004; Currall et al., 2006; Davies, 2009; Hamlett et al., 2008; Scheufele \& Lewenstein, 2005; Scheufele et al., 2007), and there is little in the way of theoretically driven, systematic, and experimental investigations of the effects of varied features of public engagements that would provide data for building theoretical models that would help explain how to maximize desired processes and outcomes (see Currall, 2009). This is not peculiar to the nanotechnology context: there have been few attempts to systematically vary critical elements of engagement techniques to study their impacts, a significant gap in the field (Delli Carpini et al., 2004).

\section{Public Engagement Social Science: Current Status and Future Directions}

There is a critical dearth of scientific knowledge across the disciplines that study engagements concerning which forms, features, and conditions are optimal for what purposes and why. This gap manifests itself in models of public engagements that are disconnected from empirical evidence, that are too general to guide decisions concerning public engagement in specific contexts or for specific purposes, and that fail to adequately explain why public engagement outcomes differ across studies. Currently, academics, practitioners, and policy makers have very little empirically based guidance for their engagement activities, with scant empirical evidence to choose or eschew involvement elements and approaches (Rowe \& Frewer, 2000, 2005). Are educationally oriented communications critical prior to an engagement, or is it sufficient to provide them at the event? Should communications follow some specific approach, or are any informational materials okay so long as they are geared for adult learners? If it is not good enough to rely on surveys for policy-making input, should consensus conferences, citizen juries, or deliberative discussions be used? Is it more effective for participants to interact face-to-face, or does online engagement suffice or have benefits that face-toface interactions do not? Does there even have to be an engagement, or would a simple opportunity to provide input after being adequately informed result in useful policy contributions? Unfortunately, the numerous calls for public engagement do not answer such questions nor do they specify which public engagement efforts are appropriate or effective for different purposes.

\section{The Challenges: Determining Which, for What, and Why}

The literature suggests three broad challenges face the social science of public participation: defining and determining (which) key features and dimensions upon which public participation activities vary are important; defining and determining major purposes of public engagement by which (for what) "effectiveness" should be evaluated; and develop- 
ing new models that explain how (or why) variations in public participation methods are causally connected to variations in effectiveness.

\section{Which: Developing Taxonomies and Dimensions of Public Participation}

Past attempts to simplify the plethora of public engagement types, mechanisms, and features have categorized types of engagement according to numerous characteristics including their different objectives, structural characteristics, inherent problems or limitations, functional attributes, extent or level of participation, information flow, ability to empower, or philosophical underpinnings (Renn \& Schweizer, 2009; Rowe \& Frewer, 2000, 2005). However, differing on one of these dimensions does not preclude different engagement mechanisms from differing on other dimensions as well, making it difficult to confidently point to specific features (or factors separate from the engagement altogether) that are responsible for inconsistent results when comparing two or more engagements.

The answer to the challenge of pinpointing "which" features of public engagement are effective for what may have an obvious answer: controlled experiments. Controlled experimental research can specifically vary certain features more narrowly and test for effects. Unfortunately, the "answer" of experiments raises two additional questions: which features should we test and (perhaps even more frequently lamented) will our results be generalizable outside of experimental contexts?

The issue of generalizability may be partially addressed by collaborations between researchers and practitioners such that experimental research is conducted in actual participatory contexts. Not all research questions can be examined this way, but some can. For example, in one of our research studies, within an actual public engagement, we randomly assigned slightly different deliberation instructions to small groups: some were asked to come to consensus on their recommendations, and others were told to form their individual opinions and then vote. Although the results of this study may or may not be generalizable to different content contexts, the results are more likely to be generalizable to discussions of city government and budgeting because the experiment took place in that actual applied context.

Setting aside the issue of generalizability, another drawback of experiments is that they are painstaking and seemingly inefficient. Carefully controlled experiments typically vary a small number of features at a time, whereas the possible features varying naturally in public engagements are myriad. The thought of systematically and experimentally testing thousands of variants is likely to make one beg for a shortcut. The need to simplify and focus on a limited number of variables within complex environments is, of course, a general challenge in social psychology and has resulted in attempts to develop situational taxonomies (e.g., Cantor, Mischel, \& Schwartz, 1982; Reis, 2008; Ten Berge \& De Raad, 1999). In light of such efforts, we propose three starting points or strategies that public engagement researchers may employ to narrow their focus and productively choose from the vast array of possibilities:

Start with what is: experimentally vary what is most commonly naturally varied or that which has implications for cost effectiveness. Two often-referenced variations include methods that 
engage individuals versus groups (e.g., individual survey responses vs. group discussion within deliberations) and those that vary in their objectives (e.g., education vs. consultation) and thus also in their cognitive demands (i.e., to learn vs. to offer useful input that holds up under critical evaluation) (Lewenstein \& Brossard, 2006). Other common variations include online versus face-to-face engagements, with online engagements typically costing less to conduct.

Start with what should be: vary the features most likely to impact engagement effectiveness. This perspective is endorsed by researchers such as Rowe and Frewer (2005), who noted that features impacting effectiveness are the most important variables in need of study. It is also consistent with efforts in social psychology to create situation taxonomies specific to certain outcomes, such as classes of situations that allow variation in certain personality traits to be observed (Ten Berge \& de Raad, 1999).

While use of this second strategy suggests that the importance of variables in terms of their impact on effectiveness needs to have been established empirically, a third strategy can assist researcher choices while empirical research is underway: vary features suggested by theory. This is perhaps the most common approach in psychology: psychologists tend to vary a narrow few but often powerful situational factors in isolation or combination in order to better understand the scope and contingencies of their effects. These second and third strategies relate to questions of "for what?" and "why?" so we expand on them later.

\section{For What: Defining "Effectiveness"}

A second challenge to advancing the social science of public participation is to define "effectiveness." In the public participation literature, calls for public engagement arise in part out of theoretical expectations of numerous benefits, including the promotion of democratic values (e.g., Ackerman \& Fishkin, 2004; Chambers, 2003; Elster, 1998; Fishkin, 1997; Gastil, 2000), enhanced social trust (Price \& Cappella, 2002), increased sophistication of political and social reasoning (Muhlberger, 2006), reduction of conflicts, and identification of common values and areas of policy agreement (e.g., International Risk Governance Council, 2007). All of these benefits might be viewed as indicators of effectiveness. Although opinions may differ on the most important indicators of the effectiveness or success of a public engagement exercise, there is some consensus that defining effectiveness should be performed in relation to the goals of a public engagement endeavor (Rowe \& Frewer, 2004). However, within nanotechnology, and paralleling the general public engagement literature, engagement efforts often aim for multiple, and oftentimes, competing goals (Abelson et al., 2003). For example, it has been suggested that successful nanotechnology-ELSI engagements would increase public knowledge of nanotechnology, public trust in regulation of nanotechnology (Macoubrie, 2005), the perceived legitimacy of nanotechnology-related decisions (McComas, Besley, \& Yang, 2008), the quality of input to policy making, and the quality of policy decisions themselves (Farrelly, 2007). However, it may be that increases in one criterion (e.g., citizen knowledge) has a detrimental impact on other criterion (e.g., public trust) (cf. Stirling, 2006; Wiedemann \& Schutz, 2005; but see Macoubrie, 2005). 
Given the number of potential effectiveness criteria that might be considered, the best strategy for moving forward is likely to be to accept and operationalize "effectiveness" as a set of constructs, many of which are multidimensional. Though values and ideals (which different people will value differently) must be considered in making the final choices concerning the relative importance of effectiveness criteria, a useful starting place is to consider them by category or type. As pointed out by others (e.g., Abelson et al., 2003; Chess \& Purcell, 1999; Rowe \& Frewer, 2004), effectiveness criteria can be categorized as follows: representation criteria, relating to the extent to which persons invited and involved are appropriately representative of all stakeholder groups (e.g., were people included from different interest groups, geographic regions, and political viewpoints, and were both layperson and nanotechnology expert views considered?); process criteria, relating to the extent to which procedures result in effective processes (e.g., during the engagement, did activities result in relevant discussion, accurate information exchange, inclusion of the diverse views and voices that were present?); and outcome criteria, relating to the products of the engagement (e.g., is the policy input obtained from the engagement competent and pertinent? Did it improve policy decisions?). Two additional criteria, sometimes categorized as process criteria, are also relevant: information criteria, relating to the selection, presentation, and interpretation of information and acceptance criteria, relating to the extent to which the public finds the engagement activities appropriate and useful (e.g., does the public view the activities as fair, democratic, worthwhile?).

As shown in Figure 1, these effectiveness criteria roughly map to the general steps involved in planning and executing a public engagement. By considering the relationships between such steps and the effectiveness criteria, researchers may be able to better focus their empirical questions on certain parts of the public engagement process. Thus, lines of research could be constructed to link methods of information selection and preparation to perceptions of that information within the context of various public engagements. Other lines of research might link methods of stakeholder selection and recruitment to representativeness criteria. Lines of research might focus across the different phases of public engagement as well. For example, do different methods of information selection and construction impact perceptions of processes differently? For example, it could be that different forms of information (e.g., expert- vs. citizen-selected information) are viewed as more acceptable by participants when used in online deliberations than when used in face-to-face deliberations.

Note that the alignment of effectiveness criteria with the various decision points associated with variation in public engagements does not narrow or limit the number of effectiveness criteria overall. Rather, it organizes those criteria in a manner that suggests directions for moving forward and beginning to strategically map out a plan for experimental investigations of public engagements. However, there are other potential ways of organizing effectiveness criteria that may also be fruitful. For example, it may also be useful to consider the psychological nature of the various effectiveness criteria. The observation that some effectiveness criteria are essentially cognitive in nature (e.g., learning outcomes) and others largely affective (e.g., satisfaction) can suggest different useful theoretical perspectives associated with different effectiveness criteria. Various theories of cognitive engagement, for example, can be used to predict, promote, and understand learning gains from engagement activities. 


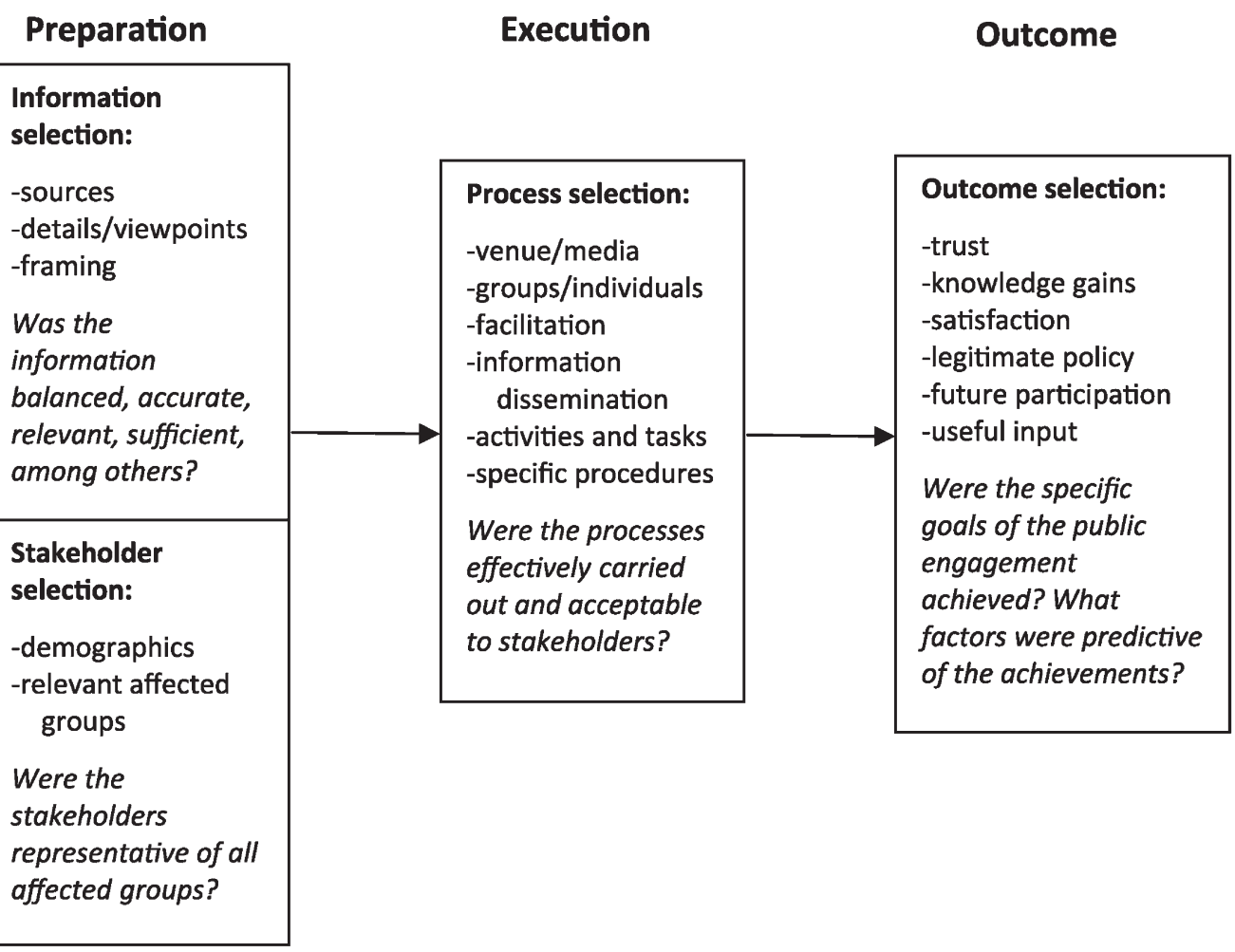

Figure 1. Relationships between Effectiveness Criteria and Phases of Planning and Executing a Public Engagement

\section{Why: A Need for Better Theoretical Models}

The ultimate challenge, a challenge that to fully meet requires defining the important features of participatory activities and the effectiveness criteria by which they should be evaluated, is to develop better theoretical models explaining the causal connections between those engagement features and effectiveness criteria. Currently, some theoretical benefits are supported (but not explained) by studies documenting positive outcomes (for reviews, see, e.g., Chilvers, 2008; Delli Carpini et al., 2004). For example, participating in engagement activities has been found to be enjoyable and educational for members of the public (Powell \& Kleinman, 2008) and to stimulate further discussions with friends and family members beyond the formalized engagement setting (Besley, Kramer, Yao, \& Toumey, 2008), as well as resulting in increases in knowledge, opinion sophistication, high levels of satisfaction (e.g., Barabas, 2004; Gastil \& Dillard, 1999; Luskin, Fishkin, \& Jowell, 2002), and positive influences on strategic decision making (e.g., Muhlberger, 2005). However, at the same time, there is contradictory theory and evidence to suggest public engagement endeavors can result in negative outcomes (e.g., Delli Carpini et al., 2004; Sunstein, 2005), such as participant dissatisfaction (e.g., Karpowitz \& Mansbridge, 2005; Mansbridge, 1983; Mendelberg \& Oleske, 2000; Smith \& Wales, 2000) 
and group conflict and polarization (e.g., Kuran \& Sunstein, 1999; Mendelberg, 2002; Spears, Lea, \& Lee, 1990; Sunstein, 2002; Walsh, 2006). In addition, in some circumstances, making decisions in groups does not increase decision accuracy but rather encourages people to solve problems at the level of the average member of the group (e.g., Barron, 2003; Gigone \& Hastie, 1997).

In light of the interests in the use of public engagement in the creation of science and technology policy, the many public engagement options available, and the inconsistent outcomes obtained from public engagement endeavors, it has been observed that "a public participation taxonomy [or model] that recommends which form of public participation to use in a particular situation" would be most welcome, especially for practitioners designing such activities; however, the existing "empirical data are not sufficient to do so with confidence" (Chess \& Purcell, 1999, p. 2690; see also, Rowe \& Frewer, 2005). Despite the decade that has elapsed since Chess and Purcell's lament, little progress has been made in the systematic and purposeful accumulation of empirical data that would allow for the construction of such taxonomies or models.

This is not to say that there have not been many suggestions concerning features that should be included in public engagement or which may enhance "successful" participation. As Rowe and Frewer (2004) noted, "[c]ertainly, there are copious suggestions in the literature about participation-exercise effectiveness, but few, if any, formalized and detailed theories" (p. 543). Commentators have called for engagement concerning nanotechnology that is transparent, open-ended, and based on the genuine willingness of policy makers and other decision makers to involve and engage the public (Powell \& Colin, 2008). In addition, general theoretical frameworks for conceptualizing the design and goals of public participation and engagement have evolved over the last couple of decades, moving from reliance on deficit models, which portray the goal of public participation as correcting the public's lack of scientific knowledge (Ziman, 1991, 1992), to other models that suggest the need to also take into account factors such as public values and contexts (contextual models; e.g., Wynne, 1996), local expertise and knowledge of affected citizens (lay expertise models; e.g., Ellen \& Harris, 1996; Wynne, 1996), and opportunities for direct engagement (public engagement models; e.g., Hamlett, 2002; Wachelder, 2003).

These common theoretical frameworks, and others such as Rowe and Frewer's (2005) information flow model, focus on the knowledge and learning processes involved in public engagement, and the learning and understanding that can be gained by policy makers who receive informed, high-quality, public input. However, as noted by Lewenstein and Brossard (2006), these models do not capture the complexity and diversity of actual science education and public engagement efforts (see also Brossard \& Lewenstein, 2009). In addition, the models fail to causally connect specific, key features of public participation to the various documented positive effects associated with participation activities (Rowe \& Frewer, 2000, 2004, 2005).

Theoretical advancement may not be too far away - a number of social, psychological, and other theories are already implicitly or explicitly referenced by current perspectives on public engagements. A broader consideration of these theories, especially in developing experimental hypotheses relevant to different features of public engagement or relevant to specific effectiveness criteria, could both expand and clarify current models. 
For example, especially relevant to deficit and contextual models of public engagement are cognitive theories of knowledge transfer, which over time, gave way to social constructivist theories of learning (McKeachie, 1990; Nix, Fraser, \& Ledbetter, 2005). Contextual engagement models also include many of the tenets of situated learning theories (e.g., Brown, Collins, \& Duguid, 1989), and they attend to participant attitudes as well, making attitude theories from social psychology relevant (e.g., Ajzen, 2001). Social theories and research on persuasion (Murphy, Holleran, Long, \& Zeruth, 2005; Tormala \& Petty, 2004) and risk perception and risk-seeking or risk-avoidance tendencies (Kahlor \& Rosenthal, 2009; McCauley, 1972) are also germane. The application of such theories to public engagement contexts could advance both public engagement theory and applied social scientific theories.

\section{The Future of Public Engagement Social Science}

As our which, for what, and why analysis suggests, major barriers to the advancement of the social science of public engagement in general (see especially, Rowe, Horlick-Jones, Walls, Poortinga, \& Pidgeon, 2008), and the problems that impede successful public contributions to nanotechnology policy in particular, include the following: the large diversity of approaches within and across engagement practices; the lack of agreement on definitions of "effective" engagement, whether the focus is on the public participants or the policy makers or in the case of scientists, others who might use the input; and the lack of theoretical or empirical attention to the reasons why or mechanisms by which certain public engagement features appear to connect to various outcomes. ${ }^{1}$ Earlier, we suggested some general ideas concerning dealing with these barriers including applying strategies for identifying features of public engagement worthy of experimental examination, focusing on various effectiveness criteria that relate to specific preparation and execution phases of engagement, and appropriately applying well-established theories from other fields, especially from social and learning sciences, in order to advance theoretical understanding of public engagement activities and outcomes. We propose that application of these general ideas would lead to a future social science of public engagement that is grounded in theory buttressed by empirical, even experimental, evidence.

Next, we describe one such application of these ideas (though there could be many) that has guided our current research involving nanotechnology public engagements. ${ }^{2}$ We started from the previously mentioned observation that two often-referenced variations in public engagement activities include methods that engage individuals versus groups and those that vary in their objectives or desired outcomes. Our very general hypothesis was that these features of public engagements will change individual- and group-level mediating processes, resulting in different impacts on individual, scientific, and policy outcomes commonly used to evaluate the effectiveness of engagement efforts. Figure 2 gives examples of such features, processes, and outcomes and illustrates a simple and flexible overarching framework. Though our framework is a preliminary one, and there are likely to be many other possibilities, such frameworks are useful "maps" that can guide research (and even engagement efforts themselves) by outlining the many possible areas of focus. 


\begin{tabular}{|c|c|c|}
\hline \multicolumn{3}{|c|}{ Public Engagement } \\
\hline Features & Processes & Outcomes \\
\hline $\begin{array}{l}\text { Procedures } \\
\text { - Individual or group } \\
\text { deliberative } \\
\text { activities } \\
\text { - Cognitive support } \\
\text { for learning or } \\
\text { critical thinking } \\
\\
\text { Moderators/Context } \\
\text { - Group composition } \\
\text { (e.g., males, } \\
\text { females) } \\
\text { - Individual } \\
\text { differences (e.g., } \\
\text { need for cognition, } \\
\text { political affiliation) }\end{array}$ & $\begin{array}{l}\text { Individual cognitive engagement } \\
\text { - Information processing/critical } \\
\text { thinking strategies } \\
\text { - Cognitive goals } \\
\text { Individual affective engagement } \\
\text { - Acceptance, perceived value } \\
\text { - Interest, flow, enjoyment } \\
\text { - Self-efficacy } \\
\text { - Affiliative, achievement goals } \\
\text { Group processes } \\
\text { - Social and information } \\
\text { exchange (quality and } \\
\text { quantity) } \\
\text { - Polarization, conformity } \\
\text { - Level of argumentation and } \\
\text { evaluation }\end{array}$ & $\begin{array}{l}\text { Participant issues } \\
\text { - Individual } \\
\text { satisfaction } \\
\text { - Increased } \\
\text { knowledge } \\
\text { - Changes in } \\
\text { institutional trust } \\
\text { - Future participation }\end{array}$ \\
\hline
\end{tabular}

Figure 2. Example Framework for Investigating Public Engagement in Science and Innovation Policy (e.g., Nanotechnology)

We developed this framework by analyzing our two targeted features of public engagement (social context and purpose), through the broad lens of multiple, social-cognitive psychological (including learning) theories. We used such theories to guide our efforts to understand why and under what conditions these differing participation features might lead to different processes and outcomes. Consistent with social-cognitive theories, we also considered theories of engagement (e.g., as reviewed by Fredricks, Blumenfeld, \& Paris, 2004), which, similarly, point to the manner in which learning environments and contexts impact diverse educational outcomes via cognitive, affective, and behavioral engagement (Newmann, Wehlage, \& Lamborn, 1992). These social-cognitive and engagement perspectives, therefore, each suggest useful mediators and methods for assessing various forms of engagement and outcomes during public engagement exercises.

In the research we currently are conducting, use of this framework directs us to attend especially to the cognitive aspects of public engagements. For example, engagements designed to educate and inform imply the need for participants to learn; engagements designed to gain critical public input imply the need for participants to think critically. Thus, narrower social-cognitive models of collaborative learning and criti- 
cal thinking are especially relevant to understanding and making hypotheses concerning the effects of social context (group vs. individual) and purpose (inform vs. consult) public engagement features (Anderson, Howe, Soden, Halliday, \& Low, 2001; Guiller, Durndell, \& Ross, 2008; Halpern, 2007; Moon, 2008; Norris, 1992; Pithers \& Soden, 2000; Wickersham \& Dooley, 2006). Consideration of these theories led us to a number of hypotheses, including that group discussion will facilitate numerous dependent variables (mediators and outcomes), such as participant engagement, factual learning, and quality of critical thinking concerning issues. Our rationale is that peer interaction in collaborative learning has been found to facilitate factual learning when peers can share information on strategies that are provided for that learning (Willoughby, Wood, McDermott, \& McLaren, 2000). ${ }^{3}$ In further support of the benefits of discussion, Levin's (1995) qualitative comparison of the effects of reading and writing concerning case studies versus additionally discussing them found that those in discussion conditions were more likely to elaborate on their original ideas, whereas those who worked alone tended simply to consolidate their original ideas (see also Flynn \& Klein, 2001). Meanwhile, others have found that elaboration of ideas significantly increases learning (Willoughby et al., 2000). Others have noted that peer discussion generally requires and enhances engagement (Levin, 1999; Thomas, 2002) and can facilitate critical thinking by challenging students' assumptions, emphasizing analysis and evaluation, and providing practice in critical thinking and listening (McDade, 1995).

Consideration of additional theories led us also to hypothesize that provision of supports for critical thinking will have additional benefits beyond those afforded from supports for learning. Especially relevant to this hypothesis is Freire's Empowerment Education Model (e.g., Freire, 1970/1993) and its recent expansion. Freire's model includes three components or phases for empowering participants: listening, dialogue, and action (Schugurensky, 1998). Recently, however, others have proposed that effective public engagement requires going beyond dialogue and the creation of understanding (i.e., learning goals) to include deliberation (i.e., critical thinking goals) concerning various options as an explicit part of the decision-making process (Downey, Anyaegbunam, \& Scutchfield, 2009; Wallerstein \& Sanchez-Merki, 1994). The need to explicitly engage citizens in critical thinking, as well as learning goals, is an important but relatively neglected part of public engagement that we thus chose to include as a focal point of our studies. The foundation of critical thinking is accurate knowledge that is then manipulated and applied in evaluating, comparing, and contrasting choices when making decisions. Although learning and critical thinking exercises may contribute similarly to factual learning, critical thinking supports, especially with peers, may also enhance engagement and the production of higher quality problem analyses and superior input.

\section{Conclusion}

We are faced with a number of challenges in order to effectively meet the commitment to effective public participation in the context of nanotechnology, in particular, or in other areas of science and innovation. These challenges arise from the complexity of the task and from the lack of prior systematic empirical research identifying and then con- 


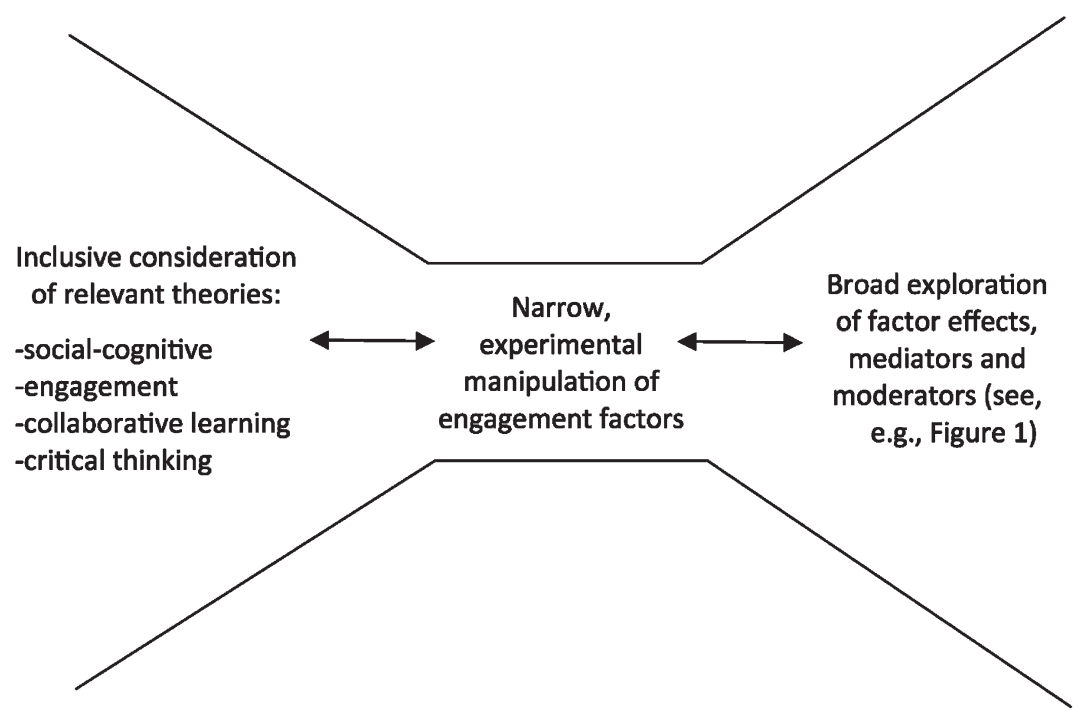

Figure 3. Research Approach for Studying Public Engagements

necting important features of public participation engagements to well-defined and valued effectiveness criteria. Given this lack of prior work and the large number of variables that might vary among different types of engagement activities, it will be important for science research funders to support inquiries that might, under other circumstances, be viewed as too ambitious in the number of variables explored or even criticized as "fishing expeditions." Complex research designs, such as fractional factorial designs (Gunst \& Mason, 2009), would be promising methods for conducting such research, but many other research approaches are also possible.

In addition, because it is easier to reach goals that are clearly identified than those that are not, we are challenged to consider and carefully define the purposes and the criteria by which public engagements should be evaluated at different phases of policy development and implementation. Are the same techniques that are useful for consideration of policy issues that are time-limited (e.g., H1N1 flu vaccine prioritization: see Bulling \& DeKraai, in press; DeKraai \& Bulling, in press) different than ones that are long term and involve the complicated interrelationships of science, technology, workforce exposure, and public safety (e.g., nanotechnology manufacturing; nanofoods)? What might be useful when controversial moral, religious, social, and ethical values are involved, such as in the case of stem cell research or the use of biobricks to create or modify living cells? Are different goals involved, and thus, different methods of public input, appropriate for considerations of science and technology that are just evolving as opposed to goals we want to posit for science and technologies that are more mature? Figure 3 provides a proposed, iterative approach for use in a program of research to address these empirical questions.

These are, at heart, public issues. Perhaps, the public itself should be involved in identifying the applicable criteria. We have documented that public engagement increases confidence in government (Tomkins, PytlikZillig, Herian, Abdel-Monem, \& Hamm, 
2010). However, although we know that trust and confidence increases, we do not know which forms of public engagement are superior for such purposes and why. In any event, until more is known concerning the manner in which different participatory features affect results of public engagements, it would be wise to use multiple types of participation for comparison purposes and evaluate processes and results not only for the benefit of systematic social science but also for optimal governance.

Finally, it is important to note that in this article, we have outlined in broad-brush form only a few of the important challenges. As the challenges we have identified are addressed, other challenges will become apparent. For example, developing models and measures is a circular process whereby theory is needed to establish measures and measures are needed to test the tenets of the models under development. Thus, another challenge to model-building efforts in the area of public engagement in science and technology policy is the lack of agreed-upon operationalizations and standardized measures for assessing various effectiveness criteria (Rowe \& Frewer, 2004; Rowe et al., 2008). Upon identifying important effectiveness criteria, as well as important features and dimensions of public participation, there will be a need for reliable and valid measures of those constructs.

Policy makers around the globe entice us with the promise of open, transparent, participatory, and collaborative government. There are contributions we believe social science can make to advance this important initiative. We are humble yet hopeful: as social scientists, we know that we know very little, we realize we need to know a lot more, and we are confident that through rigorous experimental studies and systematic programs of research, such knowledge can be gained (see, e.g., Currall, 2009). We have examined these issues in the context of nanotechnology, but the need to have "an honest conversation [by scientists] with the public about what they are doing and why" (Rejeski, 2009, p. 13) is as germane to genetic engineering policy (Cox, Kazubowski-Houston, \& Nisker, 2009; Cox \& Nisker, 2010; Nisker, Cox, \& Kazubowski-Houston, 2006; Specter, 2009) as is it is to nanotechnology policy. As social scientists and as citizens, we call for and value social science research on engagement practices because of the hope it offers for realizing the promise of a more transparent, participatory, and collaborative government - a promise that is at the heart of the democratic ideal and sound science and innovation policy.

\section{Notes}

1. One could also add other barriers, such as the lack of standardized, reliable measures of engagement processes and effectiveness criteria upon which to compare different forms of engagement. Here, however, we focus primarily on the three listed.

2. This research is currently being conducted as part of a project, "Developing a Social-Cognitive, Multilevel, Empirically-Based Model of Public Engagement for the Shaping of Science and Innovation Policy," with funding from the National Science Foundation (SBE-0965465).

3. Some public engagement research has not found increased factual learning that can be attributed to group deliberation rather than information provision (e.g., Muhlberger \& Weber, 2006). However, we reason that this may be because while public engagement activities often aim to inform citizens and/or seek citizen input, these engagement activities usually do not teach participants strategies for learning that information or thinking critically concerning the information so they can provide more valuable input. 
Acknowledgments - This article was based in part upon work supported by the National Science Foundation (NSF) under grant numbers CMMI-0709333 and SBE-0965465. Any opinions, conclusions, or recommendations expressed in this article are those of the authors and do not necessarily reflect the views of NSF.

\section{About the Authors}

Lisa M. PytlikZillig is a researcher at the Public Policy Center at the University of Nebraska, and at the Center for Instructional Innovation at the University of Nebraska-Lincoln. Her research includes public engagement, institutional confidence, use of science information in policy and other decisions, and use of technology to enhance education and engagement.

Alan J. Tomkins directs the University of Nebraska Public Policy Center. His research interests include public input to and public trust and confidence in government, public engagement to inform science policy, and issues of justice and fairness.

\section{References}

21st Century Nanotechnology Research and Development Act of 2003, 15 U.S.C. $\S \S 7501$ et seq.

Abelson, J., Forest, P.-G., Eyles, J., Smith, P., Martin, E., \& Gauvin, F.-P. (2003). Deliberations about deliberation: Issues in the design and evaluation of public consultation processes. Social Science $\mathcal{E}$ Medicine, 57, $239-251$.

Ackerman, B., \& Fishkin, J. S. (2004). Deliberation day. New Haven, CT: Yale University Press.

Ajzen, I. (2001). Nature and operation of attitudes. Annual Review of Psychology, 52, 27-58.

Anderson, T., Howe, C., Soden, R., Halliday, J., \& Low, J. (2001). Peer interaction and learning of critical thinking skills in further education students. Instructional Science, 29, 1-32.

Barabas, J. (2004). How deliberation affects policy opinions. American Political Science Review, 98, 687-701.

Barron, B. (2003). When smart groups fail. Journal of the Learning Sciences, 12, 307-359.

Besley, J. C., Kramer, V. L., Yao, Q., \& Toumey, C. (2008). Interpersonal discussion following citizen engagement about nanotechnology: What, if anything, do they say? Science Communication, 30, 209-235.

Better Regulation Executive. (2008). Code of practice on consultation. London: Department for Business, Enterprise and Regulatory Reform. Retrieved from http://www.berr.gov.uk/files/file47158.pdf

Brief Amicus Curiae in Support of Respondents Sierra Club and Judicial Watch, Inc. (2004) Cheney v. United States district court for the District of Columbia, 2004 WL 530961 (Mar 11, 2004) (No. 03-475).

Brito, J. (2008). Hack, mash, and peer: Crowdsourcing government transparency. Columbia Science and Technology Law Review, 9, 119-157.

Brossard, D., \& Lewenstein, B. V. (2009). A critical appraisal of models of public understanding of science: Using practice to inform theory. In L. Kahlor \& P. Stout (Eds.), Communicating science: New agendas in communication (pp. 11-39). New York: Routledge.

Brown, J. S., Collins, A., \& Duguid, P. (1989). Situated cognition and the culture of learning. Educational Researcher, 18, 32-42.

Bulling, D., \& DeKraai, M. (in press). Evaluation of a multistate public engagement project on pandemic influenza. Participatory Medicine.

Cantor, N., Mischel, W., \& Schwartz, J. C. (1982). A prototype analysis of psychological situations. Cognitive Psychology, 14, 45-77.

Center for Nanotechnology in Society. (2010). Homepage for the Center for Nanotechnology in Society at Arizona State University. Retrieved from http://cns.asu.edu/

Chambers, S. (2003). Deliberative democratic theory. Annual Review of Political Science, 6, 307-332.

Chess, C., \& Purcell, K. (1999). Public participation and the environment: Do we know what works? Environmental Science \& Technology, 33, 2685-2692.

Chilvers, J. (2008). Deliberating competence: Theoretical and practitioner perspectives on effective participatory appraisal practice. Science, Technology \& Human Values, 33, 421-451.

Cobb, M. D., \& Macoubrie, J. (2004). Public perceptions about nanotechnology: Risks, benefits and trust. Journal of Nanoparticle Research, 6, 395-405.

Collins, G. (2009, August 12). Gunning for health care. New York Times. Retrieved from http:// www.nytimes. com/2009/08/13/opinion/13collins.html

Cormick, C. (2009). Piecing together the elephant: Public engagement on nanotechnology challenges. Science and Engineering Ethics, 15, 439-442. 
Council for Science and Technology. (2005). Policy through dialogue: Informing policies based on science and technology. London: Council for Science and Technology.

Cox, S. M., Kazubowski-Houston, M., \& Nisker, J. (2009). Genetics on stage: Public engagement in health policy development on preimplantation genetic diagnosis. Social Science E Medicine, 68, 1472-1480.

Cox, S. M., \& Nisker, J. (2010). Public understandings of a "healthy" embryo: A citizen deliberation on preimplantation genetic diagnosis. In J. Nisker, F. Baylis, I. Karpin, C. McLeod, \& R. Mykitiuk (Eds.), The "healthy" embryo: Social, biomedical, legal, and philosophical perspectives (pp. 151-168). New York, NY: Cambridge University Press.

Currall, S. C. (2009). Nanotechnology and society: New insights into public perceptions. Nature Nanotechnology, $4,79-80$.

Currall, S. C., King, E. B., Lane, N., Madera, J., \& Turner, S. (2006). What drives public acceptance of nanotechnology? Nature Nanotechnology, 1, 153-155.

Dahl, R. A. (1994). A democratic dilemma: System effectiveness versus citizen participation. Political Science Quarterly, 109, 23-34.

Davies, S. R. (2009). Doing dialogue: Genre and flexibility in public engagement with science. Science as Culture, 18, 397-416.

DeKraai, M., \& Bulling, D. (in press). Participatory program evaluation in public engagement processes. International Journal of Public Participation.

Delli Carpini, M. X., Cook, F. L., \& Jacobs, L. R. (2004). Public deliberation, discursive participation, and citizen engagement: A review of the empirical literature. Annual Review of Political Science, 7, 315-344.

Department of Innovation, Industry, Science and Research, Australian Government. (2010). Public awareness and community engagement. Retrieved from http://www.innovation.gov.au/Industry/Nanotechnology/ PublicAwarenessandEngagement/Pages/default.aspx

Downey, L. H., Anyaegbunam, C., \& Scutchfield, D. (2009). Dialogue to deliberation: Expanding the empowerment education model. American Journal of Health Behavior, 33, 26-36.

Ellen, R. F., \& Harris, H. J. (1996). Concepts of indigenous environmental knowledge in scientific and development studies literature: A critical assessment. Retrieved from http://lucy.ukc.ac.uk/Rainforest/SML_files/ Occpap/indigknow.occpap TOC.html

ELSI Research Program. (2009). The Ethical, Legal and Social Implications (ELSI) research program. Retrieved from http://www.genome.gov/10001618

Elster, J. (Ed.). (1998). Deliberative democracy. New York: Cambridge University Press.

Ethical, Legal, and Other Societal Issues. (n.d.). National Nanotechnology Initiative. Retrieved from http:// www.nano.gov/html/society/ethical_legal_societal.html

European Commission. (2007a). Public engagement in science. Proceedings of the conference on "The future of science and technology in Europe." Retrieved from http://ec.europa.eu/research/science-society/index. $\underline{\mathrm{cfm}}$ ?fuseaction=public.topic\&id=1251

European Commission. (2007b). Taking European knowledge society seriously: Report of the expert group on science and governance. Retrieved from http://ec.europa.eu/research/science-society/document library/ pdf_06/european-knowledge-society_en.pdf

European Commission. (2008). Framework programme 7: Capacities work programme. Science in society. Retrieved from ftp://ftp.cordis.europa.eu/pub/fp7/docs/wp/capacities/sis/s_wp_200901_en.pdf

European Commission. (2009). Nanotechnology. Nanotechnology homepage of the European Commission. Retrieved from http://cordis.europa.eu/nanotechnology/

Farrelly, C. (2007). Deliberative democracy and nanotechnology. In F. Allhoff, P. Lin, \& J. Moor (Eds.), Nanoethics: The ethical and social implications of nanotechnology (pp. 215-224). New York: Wiley-Interscience.

Fenster, M. (2006). The opacity of transparency. Iowa Law Review, 91, 885-949.

Fiorino, D. (1990). Citizen participation and environmental risk: A survey of institutional mechanisms. Science, Technology E Human Values, 15, 226-244.

Fishkin, J. (1991). Democracy and deliberation. New Haven, CT: Yale University Press.

Fishkin, J. S. (1997). The voice of the people: Public opinion and democracy. (Rev. ed., new afterword). New Haven, CT: Yale University Press.

Flynn, A. E., \& Klein, J. D. (2001). The influence of discussion groups in a case-based learning environment. Educational Technology Research and Development (ETRED), 49, 71-86.

Fredricks, J. A., Blumenfeld, P., \& Paris, A. H. (2004). School engagement: Potential of the concept, state of the evidence. Review of Educational Research, 74, 59-109.

Freire, P. (1993). Pedagogy of the oppressed. New York: Continuum. (Original work published 1970.)

Fung, A., Goldman, J., McCoy, M., \& Wright, B. (2009). Working together to strengthen our nation's democracy: Ten recommendations. Report from the second conference on "Strengthening Our Nation's Democracy," Washington, DC. Retrieved from http://www.whitehouse.gov/files/documents/ostp/opengov/sond $2 \& 20$ final $\% 20$ report.pdf 
Gastil, J. (2000). By popular demand. Berkeley, CA: University of California Press.

Gastil, J., \& Dillard, J. P. (1999). Increasing political sophistication through public deliberation. Political Communication, 16, 3-25.

Gigone, D., \& Hastie, R. (1997). Proper analysis of the accuracy of group judgments. Psychological Bulletin, 121, 149-167.

Grimshaw, D. J., Stilgoe, J., \& Gudza, L. D. (2006). The role of new technologies in potable water provision: A stakeholder workshop approach. Retrieved from http://practicalaction.org/docs/ia4/nano-dialogues-2006report.pdf

Guiller, J., Durndell, A., \& Ross, A. (2008). Peer interaction and critical thinking: Face-to-face or online discussion? Learning and Instruction, 18, 187-200.

Gunst, R. F., \& Mason, R. L. (2009). Fractional factorial design. WIREs Computational Statistics, 1, $234-244$.

Halpern, D. F. (2007). The nature and nurture of critical thinking. In R. J. Sternberg, H. L. Roediger, III, \& D. F. Halpern (Eds.), Critical thinking in psychology (pp. 1-14). New York: Cambridge University Press.

Hamlett, P., Cobb, M. D., \& Guston, D. H. (2008). National Citizens' Technology Forum: Nanotechnologies and human enhancement. Phoenix: Arizona State University Center for Nanotechnology in Society. Retrieved from http:/ / cns.asu.edu/files/NCTFSummaryReportFinalFormat08.pdf

Hamlett, P. W. (2002). Technology theory and deliberative democracy. Science, Technology E Human Values, 28, 112-140.

Hamlett, P. W., \& Cobb, M. D. (2006). Potential solution to public deliberation problems: Structured deliberations and polarization cascades. Policy Studies Journal, 34, 629-648.

Holdren, J. P. (2010). Message from OSTP Director John P. Holdren. Retrieved from http://www. whitehouse. gov/open/around/eop/ostp/plan

House of Lords. (2000). Science and society. London: House of Lords.

Hullmann, A. (2008). European activities in the field of ethical, legal and social aspects (ELSA) and governance of nanotechnology. Retrieved from ftp:/ / ftp.cordis.europa.eu/pub/nanotechnology/docs/elsa governance nano.pdf

International Risk Governance Council. (2007). Nanotechnology risk governance: Recommendations for a global coordinated approach to the governance of potential risks. (Policy brief). Geneva, Switzerland: International Risk Governance Council. Retrieved from http://www.irgc.org/IMG/pdf/PB nanoFINAL2_2 .pdf

Involve. (2008). Publications. Retrieved from http://www.involve.org.uk/publications/

Jasanoff, S. (2003). Technologies of humility: Citizen participation in governing science. Minerva, 41, $223-244$.

Kahan, D. M., Braman, D., Slovic, P., Gastil, J., \& Cohen, G. (2009). Cultural cognition of the risks and benefits of nanotechnology. Nature Nanotechnology, 4, 87-90.

Kahlor, L., \& Rosenthal, S. (2009). If we seek do we learn? Predicting knowledge of global warming. Science Communication, 30, 380-414.

Karpowitz, C. F., \& Mansbridge, J. (2005). Disagreement and consensus: The importance of dynamic updating in public deliberation. In J. Gastil \& P. Levine (Eds.), The deliberative democracy handbook: Strategies for effective civic engagement (pp. 237-253). San Francisco, CA: Jossey-Bass.

Katz, E., Lovel, R., Mee, W., \& Solomon, F. (2005). Citizens' panel on nanotechnology: Report to participants. Retrieved from http://www.minerals.csiro.au/sd/SD_Publications.htm

Kaufmann, A., Audétat, M., \& Joseph, C. (2009). Risk communication and public engagement with nanotechnology. Retrieved from http://www.nanoimpactnet.eu/uploads/file/Lausanne\%20conference \% 202009/ Kaufmann.pdf

Kearnes, M., \&Wynne, B. (2007). On nanotechnology and ambivalence: The politics of enthusiasm. NanoEthics, 1, 131-142.

Kundra, V., \& Noveck, B. (2009). Transparent and open government. Retrieved from http://www.whitehouse. gov/blog/2009/05/21/transparency-and-open-government

Kuran, T., \& Sunstein, C. (1999). Availability cascades and risk regulation. Stanford Law Review, 51, 683-768.

Kyle, R., \& Dodds, S. (2009). Avoiding empty rhetoric: Engaging publics in debates about nanotechnologies. Science and Engineering Ethics, 15, 81-96.

Laffite, N. B., \& Joly, P. B. (2008). Nanotechnology and society: Where do we stand in the ladder of citizen participation? Citizen and Participation in Science and Technology Newsletter: Nanotechnology. Retrieved from http://www.cipast.org/download/CIPAST\%20Newsletter\%20Nano.pdf

Levin, B. B. (1995). Using the case method in teacher education: The role of discussion and experience in teachers' thinking about cases. Teaching and Teacher Education, 11, 63-79.

Levin, B. B. (1999). The role of discussion in case pedagogy: Who learns what? And how? In M. A. Lundeberg, B. B. Levin, \& H. L. Harrington (Eds.), Who learns what from cases and how? The research base for teaching and learning with cases (pp. 139-157). Mahwah, NJ: Lawrence Erlbaum Associates.

Lewenstein, B. V. (2005). What counts as a "social and ethical issue" in nanotechnology? HYLE, 11, 5-18.

Lewenstein, B. V., \& Brossard, D. (2006). Assessing models of public understanding in ELSI outreach ma- 
terials: Final report. Ithaca, NY: Cornell University. Retrieved from http:/ / ecommons.cornell.edu/bitstream/1813/5242/1/Lewenstein\%20and\%20Brossard.2006.DOE\%20final\%20report.pdf

Littlejohns, P., \& Rawlins, M. (Eds.). (2009). Patients, the public and the priorities in health care. Abingdon: Radcliffe.

Luskin, R. C., Fishkin, J. S., \& Jowell, R. (2002). Considered opinions: Deliberative polling in Britain. British Journal of Political Science, 32, 455-488.

Macnaghten, P., \& Guivant, J. S. (in press). Converging citizens? Nanotechnology and the political imaginary of public engagement in Brazil and the United Kingdom. Public Understanding of Science, doi: $10.1177 / 0963662510379084$.

Macnaghten, P., Kearnes, M., \& Wynne, B. (2005). Nanotechnology, governance, and public deliberation: What role for the social sciences? Science Communication, 27, 1-24.

Macoubrie, J. (2005). Informed public perceptions of nanotechnology and trust in government. Woodrow Wilson International Center for Scholars: Project on Emerging Nanotechnologies. Retrieved from http:// www. wilsoncenter.org/news/docs/macoubriereport.pdf

Mansbridge, J. (1983). Beyond adversary democracy. Chicago: University of Chicago Press.

McCauley, C. R. (1972). Extremity shifts, risk shifts and attitude shifts after group discussion. European Journal of Social Psychology, 2, 417-436.

McComas, K. A., Besley, J. C., \& Yang, Z. (2008). Risky business: Perceived behavior of local scientists and community support for their research. Risk Analysis, 28, 1539-1552.

McDade, S. A. (1995). Case study pedagogy to advance critical thinking. Teaching Psychology, 22, 9-10.

McKeachie, W. J. (1990). Research on college teaching: The historical background. Journal of Educational Psychology, 82, 189-200.

Meadowcroft, J. (2004). Deliberative democracy. In R. F. Durant, D. J. Fiorino, \& R. O. Leary (Eds.), Environmental governance reconsidered: Challenges, choices, and opportunities (pp. 177-217). Cambridge, MA: MIT Press.

Mendelberg, T. (2002). The deliberative citizen: Theory and evidence. Political Decision Making, Deliberation and Participation, 6, 151-193.

Mendelberg, T., \& Oleske, J. (2000). Race and public deliberation. Political Communication, 17, 169-191.

Mitton, C., Smith, N., Peacock, S., Evoy, B., \& Abelson, J. (2009). Public participation in health care priority setting: A scoping review. Health Policy, 91, 219-228.

Moon, J. (2008). Critical thinking: An exploration of theory and practice. New York: Routledge.

Muhlberger, P. (2005). Virtual Agora project report: Deliberated views regarding school consolidation and educational improvements in Pittsburgh. Pittsburgh, PA: Institute for the Study of Information Technology and Society, Carnegie Mellon Univ. Retrieved from http:/ /geocities.com/pmuhl78

Muhlberger, P. (2006). Should e-government design for citizen participation? Stealth democracy and deliberation. ACM International Conference Proceeding Series: Proceedings of the 2006 National Conference on Digital Government Research, 151, 53-61. Retrieved from http:// portal.acm.org/citation.cfm?id=1146620\&dl=GUIDE\&c oll=GUIDE

Muhlberger, P., \& Weber, L. M. (2006). Lessons from the Virtual Agoral Project: The effects of agency, identity, information, and deliberation on political knowledge. Journal of Public Deliberation, 2(1), 1-39.

Murphy, P. K., Holleran, T. A., Long, J. F., \& Zeruth, J. A. (2005). Examining the complex roles of motivation and text medium in the persuasion process. Contemporary Educational Psychology, 30, 418-438.

National Academy of Public Administration. (2009). Open government dialogue: How can we strengthen our democracy and promote efficiency and effectiveness by making government more transparent, participatory, and collaborative? Retrieved from http:/ / opengov.ideascale.com/

National Commission for the Protection of Human Subjects of Biomedical and Behavioral Research. (1979). The Belmont Report: Ethical principles and guidelines for the protection of human subjects of research. Washington, DC: U.S. Department of Health, Education, and Welfare. Retrieved from http://ohsr.od.nih.gov/guidelines/belmont.html

Newmann, F., Wehlage, G. G., \& Lamborn, S. D. (1992). The significance and sources of student engagement. In F. Newmann (Ed.), Student engagement and achievement in American secondary schools (pp. 11-39). New York: Teachers College Press.

Nisker, J., Cox, S. M., \& Kazubowski-Houston, M. (2006). Citizen deliberation on preimplantation genetic diagnosis. Ottawa, ON: Health Canada.

Nix, R. K., Fraser, B. J., \& Ledbetter, C. E. (2005). Evaluating an integrated science learning environment using the constructivist learning environment survey. Learning Environments Research, 8, 109-133.

Norris, S. P. (Ed.). (1992). The generalizability of critical thinking: Multiple perspectives on an educational ideal. New York: Teachers College Press.

Obama, B. H. (2009).Memorandum for the heads of executive departments and agencies: Transparency and open government. Federal Register, 74, 4685-4686. (Also available from White House Press 
Release,Memorandum for the Heads of Executive Departments and Agencies: Transparency and Open Government, Jan 21, 2009). Retrieved from http://www.whitehouse.gov/the_press office/Transparency and Open Government/

Office of Science and Technology Policy. (2010). Open government plan. Retrieved from http://www.whitehouse.gov/sites/default/files/microsites/ostp/100407-ostp-opengov-plan.pdf

Pateman, C. (1970). Participation and democratic theory. New York: Cambridge University Press.

Petersen, J. C. (Ed.). (1984). Citizen participation in science policy. Amherst, MA: University of Massachusetts Press.

Pidgeon, N., Harthorn, B. H., Bryant, K., \& Rogers-Hayden, T. (2009). Deliberating the risks of nanotechnologies for energy and health applications in the United States and United Kingdom. Nature Nanotechnology, 4, 95-98.

Pithers, R. T., \& Soden, R. (2000). Critical thinking in education: A review. Educational Research, 42, 237-249.

Powell, M., \& Kleinman, D. L. (2008). Building citizen capacities for participation in technoscientific decision making: The democratic virtues of the consensus conference model. Public Understanding of Science, 17, 329-348.

Powell, M. C., \& Colin, M. (2008). Meaningful citizen engagement in science and technology: What would it really take? Science Communication, 30, 126-136.

Price, V., \& Cappella, J. N. (2002). Online deliberation and its influence: The electronic dialogue project in Campaign 2000. IT \& Society, 1, 303-329.

Reis, H. T. (2008). Reinvigorating the concept of situation in social psychology. Personality and Social Psychology Review, 12, 311-329.

Rejeski, D. (2009, October 26). A life of its own: A letter in response to Michael Specter's article (September 28, 2009). New Yorker, p. 13. Retrieved from http://www.newyorker.com/magazine/letters/2009/10/26/091026 mama_mail1

Renn, O., \& Schweizer, P.-J. (2009). Inclusive risk governance: Concepts and application to environmental policy making. Environmental Policy and Governance, 19, 174-185.

Roco, M. C. (2003). Broader societal issues of nanotechnology. Journal of Nanoparticle Research, 5, 181-189.

Rogers-Hayden, T., \& Pidgeon, N. (2006). Reflecting upon the UK's citizens' jury on nanotechnologies: NanoJury UK. Nanotechnology Law E Business, 3, 167-178.

Rothman, D. J. (1991). Strangers at the bedside: A history of how law and bioethics transformed medical decision-making. New York: Basic Books.

Rowe, G., \& Frewer, L. J. (2000). Public participation methods: A framework for evaluation. Science, Technology E Human Values, 25, 3-29.

Rowe, G., \& Frewer, L. J. (2004). Evaluating public participation exercises: A research agenda. Science, Technology E Human Values, 29, 512-557.

Rowe, G., \& Frewer, L. J. (2005). A typology of public engagement mechanisms. Science, Technology E Human Values, 30, 251-290.

Rowe, G., Horlick-Jones, T., Walls, J., Poortinga, W., \& Pidgeon, N. (2008). Analysis of a normative framework for evaluating public engagement exercises: Reliability, validity and limitations. Public Understanding of Science, 17, 419-441.

Sargent, J. F. (2010). Nanotechnology: A policy primer.Washington, DC: Congressional Research Service. Retrieved from http://www.fas.org/sgp/crs/misc/RL34511.pdf

Scheufele, D. A., Corley, E. A., Dunwoody, S., Shih, T., Hillback, E., \& Guston, D. H. (2007). Scientists worry about some risks more than the public. Nature Nanotechnology, 2, 732-734.

Scheufele, D. A., \& Lewenstein, B. V. (2005). The public and nanotechnology: How citizens make sense of emerging technologies. Journal of Nanoparticle Research, 7, 659-667.

Schugurensky, D. (1998). The legacy of Paul Freire: A critical review of his contributions. Convergence, 31(1-2), 17-30.

Smith, G., \& Wales, C. (2000). Citizens' juries and deliberative democracy. Political Studies, 48, 51-65. Societal Dimensions. (n.d.). National Nanotechnology Initiative. Retrieved from http://www.nano.gov/html/society/ societal_dimensions.html

Solomon, F., Katz, E., Lovel, R., \& Mee, W. (2005). Talking about nanotechnologies: Experiences of public dialogue at CSIRO. Brisbane: International Conference on Engaging Communities. Retrieved from http://www.engagingcommunities2005.org/abstracts/Solomon-Fiona-final.pdf

South African Agency for Science and Technology Advancement. (2010). Nanotechnology Public Engagement Programme. Retrieved from http:/ / www.saasta.ac.za/index.php?option $=$ com content\&view $=$ article\&id $=7$ 5\&Itemid $=65$

Spears, R., Lea, M., \& Lee, S. (1990). De-individuation and group polarization in computer-mediated communication. British Journal of Social Psychology, 29, 121-134. 
Specter, M. (2009, September 28). A life of its own: Where will synthetic biology lead us? New Yorker, 56-65. Retrieved from http://www.michaelspecter.com/wp-content/uploads/Specter Synthetic Bio 9-28-09.pdf

Stirling, A. (2006). From science and society to science in society: Towards a framework for "co-operative research." (Report of European Commission Workshop, Governance and Scientific Advice Unit of DG RTD, Directorate C2, Directorate General Research and Technology Development, Brussels, 24th-25th November 2005.) Retrieved from http:/ / www.eurosfaire.prd.fr/7pc/doc/1146233108_gover_science_final_report.pdf

Sunstein, C. (2002). The law of group polarization. Journal of Political Philosophy, 10, 175-195.

Sunstein, C. (2005). Group judgments: Statistical means, deliberation, and information markets. New York University Law Review, 80, 962-1049.

Ten Berge, M. A., \& De Raad, B. (1999). Taxonomies of situations from a trait psychological perspective. A review. European Journal of Personality, 13, 337-360.

The Energy and Resources Institute (TERI). (2009). Nanotechnology developments in India - A status report. New Delhi: The Energy and Resources Institute. Retrieved from http://www.teriin.org/nano-uploads/D5_NT Development in India Apri 2010.pdf

The Energy and Resources Institute (TERI). (2010). Issues of capability and governance in nanotechnology developments. Retrieved from http:/ / www.teriin.org/index.php?option=com events\&task=details\&sid=315

Thomas, M. J.W. (2002). Learning within incoherent structures: The space of online discussion forums. Journal of Computer Assisted Learning, 2002, 351-366.

Tomkins, A. J., PytlikZillig, L. M., Herian, M. N., Abdel-Monem, T., \& Hamm, J. A. (2010). Public input for municipal policymaking: Engagement methods and their impact on trust and confidence. In S. A. Chun, R. Sandoval, \& A. Philpot (Eds.), The proceedings of the 11th Annual International Conference on Digital Government Research, Public Administration Online: Challenges and Opportunities (pp. 41-50). New York: ACM Digital Library, Digital Government Society of North America. Retrieved from http://portal.acm.org/citation.cfm?id $=1809885 \&$ jmp $=$ cit\&coll=GUIDE\&dl=GUIDE\&CFID=98220794\&CFTOKEN=99331109\#CIT

Tormala, Z. L., \& Petty, R. E. (2004). Resistance to persuasion and attitude certainty: The moderating role of elaboration. Personality and Social Psychology Bulletin, 30, 1446-1457.

Urbina, I. (2009, August 7). Beyond Beltway, health debate turns hostile. New York Times. Retrieved from http:/ / www.nytimes.com/2009/08/08/us/politics/08townhall.html?.r=1\&scp=1\&sq=town \% 20hall \%20 meetings \% 20health\%20care\%20reform\&st=cse

Urbina, I., \& Seelye, K. Q. (2009, August 11). Senator goes face to face with dissent. New York Times. Retrieved from http:/ / www.nytimes.com/2009/08/12/health/policy/12townhall.html?scp=6\&sq=town $\% 20$ hall $\% 20$ meetings $\% 20$ health $\% 20$ care $\% 20$ reform\&st=cse

Verba, S., \& Nie, N. H. (1972). Participation in America. New York: Harper and Row.

Wachelder, J. (2003). Democratizing science: Various routes and visions of Dutch science shops. Science, Technology \& Human Values, 28, 244-273.

Wallerstein, N., \& Sanchez-Merki, V. (1994). Freirian praxis in health education: Research results from and adolescent prevention program. Health Education Research, 9, 105-118.

Walsh, K. C. (2006). Communities, race, and talk: An analysis of the occurrence of civic intergroup dialogue programs. Journal of Politics, 68, 22-33.

Weisstub, D. (Ed.). (1998). Research on human subjects: Ethics, law, and social policy. Oxford: Elsevier Science, Ltd.

Wickersham, L. E., \& Dooley, K. E. (2006). A content analysis of critical thinking skills as an indicator of quality of online discussion in virtual learning communities. Quarterly Review of Distance Education, 7, 185-193.

Wiedemann, P. M., \& Schutz, H. (2005). The precautionary principle and risk perception: Experimental studies in the EMF area. Environmental Health Perspectives, 113, 402-405.

Willoughby, T., Wood, E., McDermott, C., \& McLaren, J. (2000). Enhancing learning through strategy instruction and group interaction: Is active generation of elaborations critical? Applied Cognitive Psychology, 14, 19-30.

Wilsdon, J., \& Willis, R. (2004). See-through science: Why public engagement needs to move upstream. London: Demos.

Wynne, B. (1996). May the sheep safely graze? A reflexive view of the expert-lay knowledge divide. In S. Lash, B. Szerszynski, \& B. Wynne (Eds.), Risk, environment and modernity: Towards a new ecology (pp. 44-83). London: Sage.

Ziman, J. (1991). Public understanding of science. Science, Technology \& Human Values, 16, 99-105.

Ziman, J. (1992). Not knowing, needing to know, and wanting to know. In B. V. Lewenstein (Ed.), When science meets the public (pp. 13-20). Washington, DC: American Association for the Advancement of Science. 